\title{
Economic viability of pitaya (Hylocereus sp.) Cultivation in Tomé-Açú Municipality, Pará State, Brazil
}

João Paulo Borges de Loureiro, Olivia Masako Hanawa Lima, Juliana de Sousa Farias, Adriana Paiva dos Praseres Pires, Marcos Antônio Souza dos Santos, Fabrício Khoury Rebello, Andréia Santana Bezerra

Federal Rural University of Amazon (UFRA), Brazil

Received: May 3, 2020

doi:10.5296/jas.v8i2.16949
Accepted: May 27, $2020 \quad$ Published: May 29, 2020

URL: https://doi.org/10.5296/jas.v8i2.16949

\begin{abstract}
Pitaya (Hylorereus sp.) is a fruit from the botanical family Cactaceae, originally from Latin America. In Brazil, pitaya cultivation is promising due to the fruit's reputation of being nutritious and having many uses. This study's objective was to analyze the economic viability of two pitaya production systems in Tomé-Açu municipality, the largest producer of pitaya in the Pará state, Brazilian Amazon. The data were obtained through interviews with two producers, along with field observations of their production systems, which are representative of the cultivation norms in Tomé-Açu. The data were used to estimate the planting and maintenance costs for 1 ha of land using different cultivation methods, identified as: 1) extensive production system and 2) intensive production system. The two systems' cash flows were estimated over a 20-year period, then analyzed to estimate the net present value, internal rate of return, benefit-cost index, payback period, and break-even point. The intensive production system was found to have a higher implementation cost, due to its irrigation system, while the extensive production system was found to have lower investment and maintenance costs. The economic viability indicators show that both production systems are economically viable, with the extensive production system being more attractive, especially for family farmers who cannot invest in expensive irrigation infrastructure and chemical inputs. In conclusion, the investment in pitaya cultivation is economically viable and constitutes an alternative to agricultural cultivation in Pará state, which can contribute to fruit diversification.
\end{abstract}

Keywords: fruit growing, production systems, economic analysis, amazon 


\section{Introduction}

Pitaya (Hylorereus sp.), also known as dragon fruit, is a rustic fruit from the botanical family Cactaceae, originally from Latin America, mainly from Mexico, and is now being disseminated worldwide in tropical and subtropical regions (Perween et al., 2018; Mizrahi et al., 1997; Esquivel \& Ayara-Quesada, 2012).

Since the 1990s, Brazilian producers have been investing in pitaya commercial planting and, currently, it is grown in several regions of the country (Bastos et al., 2006). It is a crop with great economic and agronomic potential, and it can be cultivated in sandy, stony, and rocky soils, due to its low nutritional requirement and resistance to low water availability (Junqueira et al., 2010). Despite the pitaya's rusticity and adaptation to various climatic conditions, organic fertilization assumes a fundamental role, as it provides essential nutrients, such as nitrogen, phosphorus, and potassium (Hernandez, 2000).

Pitaya's average productivity varies according to soil and climatic conditions, cultivation techniques, and orchard age. The annual production per plant at four years of age is $25 \mathrm{~kg}$, with a yield of around 10 to $30 \mathrm{t} \mathrm{ha}^{-1}$ in the crop stabilization period, depending on the planting density (Marques, 2012).

Pitaya cultivation has proved to be a promising agricultural activity in economic terms, as it has good acceptance in the consumer market (Junqueira et al., 2002), mainly due to its nutraceutical properties and health benefits (Perween et al., 2018; Melquíades Júnior, 2018). This fruit stands out for its high vitamin $\mathrm{C}$ and complex B vitamins (B1, B2, and B3) content, and high levels of fiber, flavonoids, nitrogen, potassium, calcium, iron, manganese, and zinc (Cordeiro et al., 2015).

The fruit is nutritious and has a wide variety of uses, with pulp constituting between $70 \%$ to $80 \%$ of it. It can be consumed either fresh or processed by the food industry into products such as ice cream, jellies, juices, wines, teas, syrups, sweets, and natural dyes (Pushpakumara et al., 2007; Greenme, 2017), as well as being used in medicines and in the production of cosmetics (Pitaya do Brasil, 2019).

In Pará state, pitaya has been cultivated in several municipalities, including Tomé-Açu, in Pará Northeast, an important area for the implementation of Agroforestry Systems (SAFs) in the Brazilian Amazon, where fruit production is a major source of livelihood, and where the agribusiness of fruit pulp processing has been consolidated. Data from the 2017 Agricultural Census (IBGE, 2019) indicate that 59.28\% of Pará's annual pitaya production (156.4 tons) comes from this municipality.

Fróes Júnior et al. (2019) highlight that this cultivation is ongoing in Pará state, with small producers being the main contributors. However, there has been an increase in the number of larger producers with expertise in intensive fruit production. Despite the great potential for the expansion of cultivation, Fróes Júnior et al. (2009) estimate that pitaya represents only $0.02 \%$ of fruit production in Pará state. This is because fruit production in Pará state contributes considerably to national production, with fruits such as açaí, pineapple, coconut-of-the-bay, cocoa, and Brazil nuts, as can be seen in a recent study by Embrapa 
Eastern Amazon (Costa et al., 2017).

There is a lack of previous studies to guide the expansion of pitaya cultivation in Pará state, specifically on the production costs and economic viability of the cultivation system under local conditions (Fróes Júnior et al., 2019). An adequate budget is needed to estimate the investment required to implement a cultivation system, in addition to calculating cash flow requirements and evaluating the crop's profitability (Oliveira et al., 2010). In addition, surveys about production, commercialization, and socioeconomic aspects are fundamental to understand this new market and to define strategies that encourage an increase in fruit supply by rural producers.

Despite the growth in demand and profitability of pitaya, it is important to not only conduct research on genetics and management, but also economic analysis in the Tomé-Açu municipality, as it is currently the main crop-producing municipality in Pará state.

In this regard, this study's objective is to analyze the economic viability of two different pitaya production systems, in order to verify which one is the best option for cultivation in the Tomé-Açu municipality.

This type of study is important to guide private investments; it provides a basis for budget planning and information on profitability and business potential to rural credit banks.

\section{Method}

Data collection took place in April 2019, with two rural producers who work with the pitaya culture in the Tomé-Açu municipality. Information was collected in two ways: 1) a questionnaire, with open questions, which was completed by the producers and 2) field observations on practices in the production systems. The questions enquired about planting and maintenance costs for 1 ha of land, using different cultivation methods, identified as: 1) extensive production system and 2) intensive production system. In addition to the cost information from producers, the opportunity cost of capital was also considered, specifically, the average savings income in 2018 (6\% per year). The prices paid to producers, according to sales channels, were also obtained from producers, as well as data on inputs and technologies used.

Data were analyzed using Microsoft Excel; production costs were calculated and cash flows were forecasted with a planning horizon of 20 years, which is the estimated useful life of a pitaya plantation according to Pushpakumara et al., (2007). Based on these cash flow forecasts, the following economic viability indicators were estimated: net present value (NPV), internal rate of return (IRR), benefit-cost index (BCI), payback period, and break-even point (Blank \& Tarquin, 2012), using interest rates from different financing sources. It is worth noting that the discount rates used in the feasibility calculations were among the main financing lines available to family farmers in the Brazilian Amazon, with rates ranging from $2 \%$ to $10 \%$ per year. 


\section{Results and Discussion}

\subsection{Characterization of Production Systems}

The production systems' typology was created using the characteristics of technology, spacing, and adopted handling for two properties, as shown in Table 1.

Table 1. Characterization of pitaya production systems in the study area

\begin{tabular}{lll}
\hline Characteristics & Intensive system & Extensive system \\
\hline Use of Irrigation & Yes & No \\
\hline Spacing & $2,5 \mathrm{~m} \times 2,5 \mathrm{~m}$ & $3 \mathrm{~m} \times 4 \mathrm{~m}$ \\
\hline Feet (number per ha) & 1600 (square) & 834 (triangular) \\
\hline Fertilizer type & Synthetic & Organomineral \\
\hline Fertilizing method & Ferti-irrigation & Guide \\
\hline
\end{tabular}

Source: Research data, 2019

The data corresponds to the installation and maintenance phases of production, and includes sources of costs, such as cleaning, harvesting and, marketing fruits. These costs were systematized and transformed into cash flows, considering the sale price of $\mathrm{R} \$ 4.00 / \mathrm{kilo}$ offered to the producer by the Tomé-Açu Mixed Agricultural Cooperative (Cooperativa Agrícola Mista de Tomé-Açu - CAMTA). This price was chosen because CAMTA represents the main sales channel for producers. It is important to note that producers in the municipality have an option of three sales channels, each with different pricing, as well as different criteria for purchasing the product.

Intermediary fruit traders from other municipalities come to Tomé-Açu when there is a lack of supply in their regions. However, this is an inconsistent channel, which depends directly on a lack of production by farmers in those regions. Supply Center of Pará State (Centrais de Abastecimento do Estado do Pará - CEASA) is located in the state capital (Belém); therefore, an additional freight cost is necessary; fruits that are unsold are returned. CAMTA offers a lower price, but is able to purchase the total quantity produced by the farmer, and requires constant supply.

Table 2. Prices paid per kilogram of pitaya in the Tomé-Açu municipality, Pará state.

\begin{tabular}{ll}
\hline Sales channel & Price $\left(\mathrm{R} \$ \mathrm{~kg}^{-1}\right)$ \\
\hline Intermediaries & 6.00 \\
\hline CAMTA & 4.00 \\
\hline CEASA & 6.00 \\
\hline
\end{tabular}

Source: Research data, 2019. 


\section{Macrothink}

The productivity curves for each production system were also considered so that cash flows could be assessed-using the five economic viability indicators mentioned in the methodology - to identify which production system is most profitable.

Data that suggest a drop in pitaya productivity were not found in the literature, nor in the researched areas. In view of this, productivity was assumed-after attaining productive stability — to be constant during its useful life (20 years), for both the intensive (Figure 1) and extensive production systems (Figure 2).

Intensive production starts with a total of $1600 \mathrm{~kg} \mathrm{ha}^{-1}$ in the first year, followed by $8000 \mathrm{~kg}$ $\mathrm{ha}^{-1}$ in the second, then reaches productive stability in the third year, with $16000 \mathrm{~kg} \mathrm{ha}^{-1}$ (Figure 1).

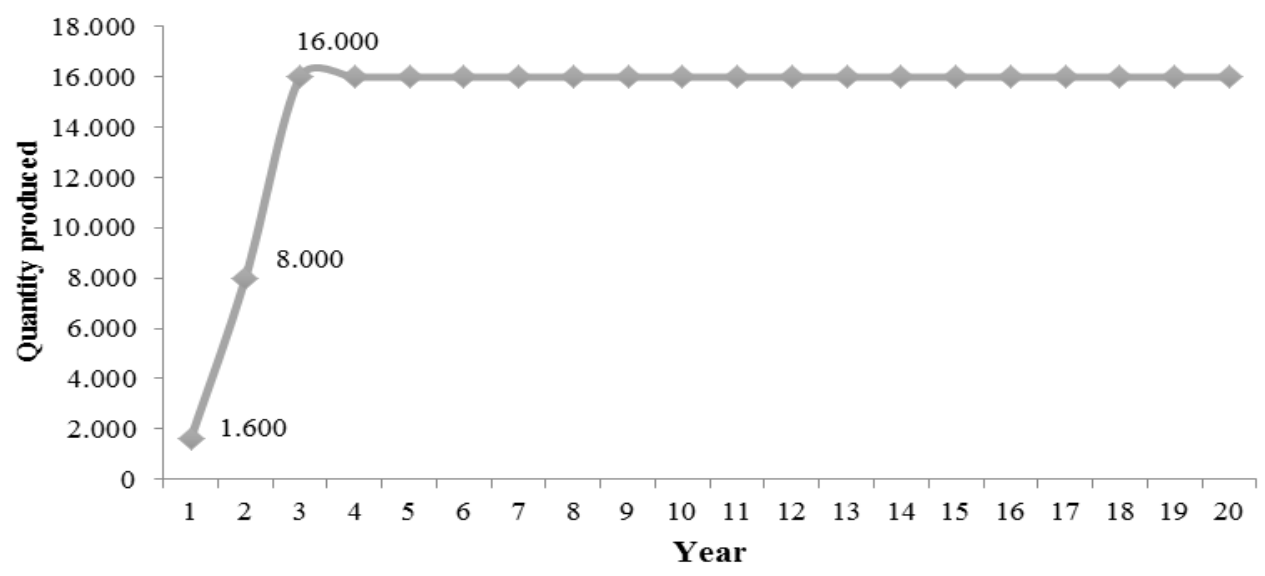

Figure 1. Pitaya productivity curve for the intensive production system $\left(\mathrm{kg} \mathrm{ha}^{-1}\right)$

Source: Research data, 2019

Extensive production starts with $834 \mathrm{~kg} \mathrm{ha}^{-1}$ in the first year, then, unlike intensive production, reaches stability in the second year, with $16680 \mathrm{~kg} \mathrm{ha}^{-1}$ (Figure 2).

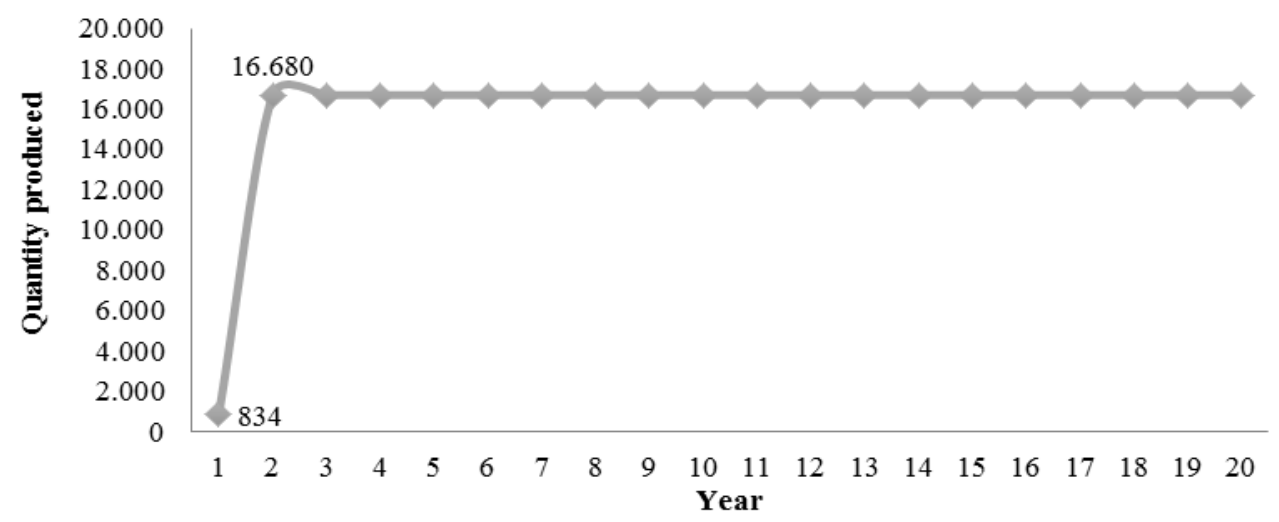

Figure 2. Pitaya productivity curve for the extensive production system $\left(\mathrm{kg} \mathrm{ha}^{-1}\right)$

Source: Research data, 2019 


\subsection{Cash Flows and Economic and Financial Viability Indicators}

Table 3 shows the cash flow for the intensive production system for each year, specifically, costs, the revenue generated by production, net cash flow (NCF), and accumulated cash flow (ACF). We identified variations in costs, which are repeated every 5 to 6 years, due to the replacement of depreciated implements.

Table 3. Cash flow: Intensive production system

\begin{tabular}{crrrr}
\hline Year & Cost $(\mathrm{R} \$)$ & Revenue $(\mathrm{R} \$)$ & NCF $(\mathrm{R} \$)$ & \multicolumn{1}{c}{ ACF $(\mathrm{R} \$)$} \\
\hline 0 & 69991.19 & - & -69991.19 & -69991.19 \\
\hline 1 & 18382.42 & 6400.00 & -11982.42 & -81973.62 \\
\hline 2 & 15425.19 & 32000.00 & 16574.81 & -65398.81 \\
\hline 3 & 15425.19 & 64000.00 & 48574.81 & -16824.00 \\
\hline 4 & 15425.19 & 64000.00 & 48574.81 & 31750.81 \\
\hline 5 & 15425.19 & 64000.00 & 48574.81 & 80325.61 \\
\hline 6 & 17280.47 & 64000.00 & 46719.53 & 127045.14 \\
\hline 7 & 15425.19 & 64000.00 & 48574.81 & 175619.95 \\
\hline 8 & 15425.19 & 64000.00 & 48574.81 & 224194.75 \\
\hline 9 & 15425.19 & 64000.00 & 48574.81 & 272769.56 \\
\hline 10 & 26825.19 & 64000.00 & 37174.81 & 309944.37 \\
\hline 11 & 17280.47 & 64000.00 & 46719.53 & 356663.89 \\
\hline 12 & 15425.19 & 64000.00 & 48574.81 & 405238.70 \\
\hline 13 & 15425.19 & 64000.00 & 48574.81 & 453813.51 \\
\hline 14 & 15425.19 & 64000.00 & 48574.81 & 502388.32 \\
\hline 15 & 20091.69 & 64000.00 & 43908.31 & 546296.62 \\
\hline 16 & 16946.97 & 64000.00 & 47053.03 & 593349.65 \\
\hline 17 & 14627.87 & 64000.00 & 49372.13 & 642721.78 \\
\hline 18 & 14627.87 & 64000.00 & 49372.13 & 692093.90 \\
\hline 19 & 14627.87 & 64000.00 & 49372.13 & 741466.03 \\
\hline 20 & 14627.87 & 64000.00 & 49372.13 & 790838.16 \\
\hline
\end{tabular}

Source: Research data, 2019

By analyzing the economic viability indicators, as well as the different financing rates offered to the farmer, shown in Table 4, we could report that intensive production, based on a rate of $5 \%$, has an NPV of R $\$ 437545.37$ at the end of the 20-year period of the investment project. This value is the net profit, since all costs generated by production, including maintenance, have already been discounted. The pitaya benefit-cost index shows that, on the initial investment value, the project generates a gross profit of $\mathrm{R} \$ 7.25$, that is, for each real invested, the producer obtains a net return of $\mathrm{R} \$ 6.75$. If a loan or bank financing is required to fund the project's implementation, the internal rate of return (IRR) is used to verify the maximum rate supported by the investment; in this case the IRR was $36.63 \%$.

Considering the payback (PB) of 3 years and 4 months and the 20-year useful life of a pitaya plantation, this activity is attractive, since it has a quick return and continues to generate revenue in the long run. The break-even point is $2091 \mathrm{~kg}$ per year, which is a reasonable amount when compared to total production capacity. 
Table 4. Economic viability indicators of the intensive production system with different financing sources

\begin{tabular}{llll}
\hline & PRONAF More Food & Mini FNO Rural & Private credits \\
\hline Interest rate & $2.0 \%$ & $5.0 \%$ & $10 \%$ \\
\hline NPV & $\mathrm{R} \$ 619293.49$ & $\mathrm{R} \$ 437545.37$ & $\mathrm{R} \$ 255064.23$ \\
\hline BCI & $\mathrm{R} \$ 9.85$ & $\mathrm{R} \$ 7.25$ & $\mathrm{R} \$ 4.64$ \\
\hline IRR & $36.63 \%$ & $36.63 \%$ & $36.63 \%$ \\
\hline PB & 3 years and 4 months & 3 years and 4 months & 3 years and 4 months \\
\hline BEP & $2091 \mathrm{~kg}$ & $2091 \mathrm{~kg}$ & $2091 \mathrm{~kg}$ \\
\hline
\end{tabular}

The extensive production system, compared with the intensive production system, has a much lower initial investment value, because it does not use an irrigation system (Table 5). As with the intensive production system, changes in costs are also identified every 5 to 6 years, due to the replacement of depreciated implements.

Table 5. Cash flow: Extensive production system

\begin{tabular}{c|rrrr}
\hline Year & Cost $(\mathrm{R} \$)$ & Revenue $(\mathrm{R} \$)$ & NCF $(\mathrm{R} \$)$ & \multicolumn{1}{c}{ ACF $(\mathrm{R} \$)$} \\
\hline 0 & 12134.01 & - & -12134.01 & -12134.01 \\
1 & 14843.03 & 3336.00 & -11507.03 & -23641.04 \\
2 & 14589.05 & 66720.00 & 52130.95 & 28489.91 \\
3 & 14589.05 & 66720.00 & 52130.95 & 80620.86 \\
4 & 14589.05 & 66720.00 & 52130.95 & 132751.80 \\
5 & 14670.88 & 66720.00 & 52049.12 & 184800.92 \\
6 & 14789.50 & 66720.00 & 51930.50 & 236731.42 \\
7 & 14589.05 & 66720.00 & 52130.95 & 288862.37 \\
8 & 14589.05 & 66720.00 & 52130.95 & 340993.32 \\
9 & 14589.05 & 66720.00 & 52130.95 & 393124.27 \\
10 & 14670.88 & 66720.00 & 52049.12 & 445173.38 \\
11 & 14789.50 & 66720.00 & 51930.50 & 497103.88 \\
12 & 14589.05 & 66720.00 & 52130.95 & 549234.83 \\
13 & 14589.05 & 66720.00 & 52130.95 & 601365.78 \\
14 & 14589.05 & 66720.00 & 52130.95 & 653496.73 \\
15 & 14670.88 & 66720.00 & 52049.12 & 705545.85 \\
16 & 14744.33 & 66720.00 & 51975.67 & 757521.51 \\
17 & 14518.48 & 66720.00 & 52201.52 & 809723.03 \\
18 & 14518.48 & 66720.00 & 52201.52 & 861924.55 \\
19 & 14518.48 & 66720.00 & 52201.52 & 914126.07 \\
20 & 14518.48 & 66720.00 & 52201.52 & 966327.59 \\
\hline
\end{tabular}

Source: Research data, 2019

Extensive production is more economically viable than intensive production (Table 6), using the same rural financing rate $(5 \%)$ for analysis. The NPV indicates that the activity is 
economically viable since it has a positive balance of $\mathrm{R} \$ 536959.56$ at the end of the investment project. The $\mathrm{BCI}$ is $\mathrm{R} \$ 45.25$, indicating that for each currency unit ( $\mathrm{R} \$ 1.00)$ invested, there will be a net return of $\mathrm{R} \$ 44.25$. This high return can be used by producers to invest in increasing production, or even diversifying with other agricultural crops.

The IRR for the external production system indicates that the investment is lucrative for farmers due to the high profit margin, which indicates a quick return on the invested capital. Another relevant result is the break-even point, which is $1530 \mathrm{~kg}$; a much lower value if purchased at production capacity in the stability phase.

The payback period is approximately 2 years and 5 months, which makes the activity attractive, and reduces the risk of default if financing is required, since most rural loans allow a grace period in initial payment of between 3 and 4 years.

Table 6. Economic viability indicators of the extensive production system with different financing sources

\begin{tabular}{llll}
\hline & PRONAF More Food & Mini FNO Rural & Private credits \\
\hline Interest rate & $2 \%$ & $5 \%$ & $10 \%$ \\
\hline NPV & $\mathrm{R} \$ 750055.12$ & $\mathrm{R} \$ 536959.56$ & $\mathrm{R} \$ 327468.69$ \\
\hline BCI & $\mathrm{R} \$ 62.81$ & $\mathrm{R} \$ 45.25$ & $\mathrm{R} \$ 27.99$ \\
\hline IRR & $131.59 \%$ & $131.59 \%$ & $131.59 \%$ \\
\hline PB & 2 years and 5 months & 2 years and 5 months & 2 years and 5 months \\
\hline BEP & $1530 \mathrm{~kg}$ & $1530 \mathrm{~kg}$ & $1530 \mathrm{~kg}$ \\
\hline
\end{tabular}

Despite the extensive production system being less complex than the intensive production system, the data in Tables 6 and 4 demonstrate it is more profitable. This is mainly due to the type of fertilization used and the method employed to apply it, as can be seen in Table 7, where irrigation and ferti-irrigation cover a significant percentage of the total cost for the implementation of the intensive production system. Additionally, the spacing and use of synthetic fertilizers contributes to this system being less profitable. 
Table 7. Costs of implementing the intensive production system

\begin{tabular}{lll}
\hline & $\begin{array}{l}\text { Amount invested } \\
(\mathbf{R} \mathbf{)})\end{array}$ & $\begin{array}{l}\text { \% of total } \\
\text { implementation cost }\end{array}$ \\
\hline Area cleaning & $\mathbf{2 9 3 0 . 0 0}$ & $\mathbf{4 . 1 9 \%}$ \\
\hline (Lie down) crawler tractor & 1200.00 & \\
\hline $\begin{array}{l}\text { (Windrow, harrowing, and liming) } \\
\text { Conventional tractor }\end{array}$ & 1350.00 & $\mathbf{2 2 . 0 9 \%}$ \\
\hline Limestone & 380.00 & \\
\hline Fertilization & $\mathbf{1 5 4 6 0 . 8 0}$ & \\
\hline Yoorin & 1108.80 & $\mathbf{0 . 1 3 \%}$ \\
\hline Bone meal & 4192.00 & \\
\hline Castor pie & 10080.00 & \\
\hline Labor for fertilization & 80.00 & \\
\hline Picking & $\mathbf{8 9 . 3 9}$ & \\
\hline Rope & 49.39 & \\
\hline Labor for picking & 40.00 & \\
\hline Planting support post cuttings $/$ & $\mathbf{1 6 0 7 1 . 0 0}$ & \\
planting pits & 1600.00 & $\mathbf{4 4 . 8 6 \%}$ \\
\hline Planting support post cuttings & 31.00 & $\mathbf{5 . 7 7 \%}$ \\
\hline Hoe & 14400.00 & \\
\hline Planting support & 40.00 & \\
\hline Labor for planting pits & $\mathbf{4 0 4 0 . 0 0}$ & \\
\hline Planting & 4000.00 & \\
\hline Seedlings & 40.00 & $\mathbf{3 1 4 0 0 . 0 0}$ \\
\hline Labor for planting & 14400.00 & \\
\hline Ferti-irrigation (Fertilizing method) & 10000.00 & \\
\hline Artesian well & 600.00 & \\
\hline Irrigation system & 1400.00 & \\
\hline Preparing to receive the irrigation system & \\
\hline Water tank & 5000.00 & \\
\hline Irrigation system deposit & $\mathbf{6 9 9 9 1 . 1 9}$ & \\
\hline Total & & \\
\hline & & \\
\hline
\end{tabular}

Source: Research data, 2019

Table 8 reinforces the main reasons for the differences in the results of the viability indicators of the two systems. As can be seen, while the intensive production system has a high cost for ferti-irrigation - which alone costs more than the entire extensive production system, and represents $44.86 \%$ of the total cost of implementing the system - the extensive production system's manual fertilization process represents only $27.08 \%$ of the total cost of implementation. Thus, in order to better manage the intensive production system and, consequently, lead to an increase in profitability, it is necessary to seek innovations that reduce the cost of implementing irrigation and ferti-irrigation. 
Table 8. Costs of implementing the extensive production system.

\begin{tabular}{lll}
\hline & $\begin{array}{l}\text { Amount invested } \\
(\mathbf{R} \mathbf{\$})\end{array}$ & $\begin{array}{l}\text { \% of total } \\
\text { implementation cost }\end{array}$ \\
\hline Area cleaning & $\mathbf{1 1 5 6 . 2 5}$ & $\mathbf{9 . 5 3 \%}$ \\
\hline Area opening (tractor) & 1100.00 & \\
\hline Conventional tractor (harrow) & 56.25 & $\mathbf{4 6 . 2 1 \%}$ \\
\hline Picking & $\mathbf{5 6 0 6 . 9 6}$ & \\
\hline Rope & 55.56 & \\
\hline Labor for picking & 100.00 & \\
\hline Planting support & 4587.00 & $\mathbf{1 7 . 1 8 \%}$ \\
\hline Bico de pato & 30.40 & $\mathbf{2 7 . 0 8 \%}$ \\
\hline Labor for planting support post cuttings & 834.00 & \\
and planting pits & $\mathbf{2 0 8 5 . 0 0}$ & \\
\hline Planting & 2085.00 & \\
\hline Seedlings & $\mathbf{3 2 8 5 . 8 0}$ & \\
\hline Fertilization & 975.60 & \\
\hline Yoorin Master & 172.50 & \\
\hline Algen & 324.00 & \\
\hline Potassium chloride $(\mathrm{KCl})$ & 95.10 & \\
\hline Borax soil & 282.00 & \\
\hline Amiorgan & 9.60 & \\
\hline Palm kernel meal & 1140.00 & \\
\hline Composting & 160.00 & \\
\hline Labor for planting and fertilization & 127.00 & $\mathbf{1 2 1 3 4 . 0 1}$ \\
\hline Pushcart & & \\
\hline Total & & \\
\hline & & \\
\hline
\end{tabular}

Source: Research data, 2019

\section{Conclusion}

We conclude that pitaya culture cultivation is economically viable using either of the two studied production systems; however, the more profitable alternative, from the point of view of planting and maintenance, is the extensive production system, as it presents better economic viability indicators.

The intensive production system is less viable due to crop management practices. The dense spacing and the need to fertilize with synthetic fertilizers by means of ferti-irrigation, substantially increase production costs. In this context, this system is a less attractive investment option, especially for family farmers who have little capital to invest in infrastructure and chemical inputs. 


\section{Acknowledgments}

This study was financed in part by the Coordenação de Aperfeiçoamento de Pessoal de Nível Superior - Brasil (CAPES). Finance Code 001.

\section{References}

Bastos, D. C., Pio, R., Scarpare Filho, J. A., Libardi, M. N., Almeida, L. F. P., Dias Galuchi, T. P., \& Bakker, S. T. (2006). Propagação da Pitaya Vermelha por estaquia. Ciência e Agrotecnologia, Lavras, 30, 1106-1109. https://doi.org/10.1590/S1413-70542006000600009

Blank, L., \& Tarquin, A. (2012). Engineering economy. (7th ed.). New York: McGraw-Hill.

Cordeiro, M. H. M., Silva, J. M., Mizobutsi, G. P., Mizobutsi, E. H., \& Mota, W. F. (2015). Caracterização física, química e nutricional da pitaia-rosa de polpa vermelha. Revista Brasileira de Fruticultura, Jaboticabal, 37, 20-26. https://doi.org/10.1590/0100-2945-046/14

Costa, M. R. T. R., Homma, A. K. O., Rebello, F. K., Souza Filho, A. P. S., Fernandes, G. L. C., \& Baleixe, W. (2017). Atividade agropecuária no estado do Pará. Belém: Embrapa Amazônia Oriental, p. 174 [Online] Available: https://www.embrapa.br/busca-de-publicacoes/-/publicacao/1073940/atividade-agropecuariano-estado-dopara (March 17, 2019)

Esquivel, P., \& Ayara-Quesada, Y. (2012). Características del fruto de la pitahaya (Hylocereus sp.) y su potencial de uso en la industria alimentaria. Revista Venezolana de Ciencia y Tecnología de Alimentos, 3, 113-129. Depósito Legal: ppi201002CA3536. [Online] Available: https://sites.google.com/site/1rvcta/v3-n1-2012/r7 (May 6, 2019)

Fróes Júnior, P. S. M., Cardoso, N. R. P., Rebello, F. K., Homma, A. K. O., \& Lopes, M. L. B. (2019). Aspectos da produção, comercialização e desenvolvimento da cultura da pitaya no estado do Pará. Enciclopédia Biosfera, 16, 264-279. https://doi.org/10.18677/EnciBio_2019A19

Hernandez, Y. D. O. (2000). Hacia el conocimiento e la conciervación de la pitahaya (hylocereus sp). Oxaca: IPN-SIBEJ-CONACYT-FMCN, p. 124.

IBGE - Instituto Brasileiro de Geografia e Estatística. (2017). Resultados do Censo Agropecuário 2017. [Online] Available: https://censos.ibge.gov.br/agro/2017/ (March 1, 2019)

Junqueira, K. P. et al. (2002). Informações preliminares sobre uma espécie de pitaya. Planaltina: EMBRAPA Cerrados, p. 18.

Junqueira, K. P. et al. (2010). Variabilidade genética de acessos de pitaya com diferentes níveis de produção por meio de marcadores RAPD1. Revista Brasileira de Fruticultura, Jaboticabal, 32, 840-846. https://doi.org/10.1590/S0100-29452010005000107

Marques, V. B. et al. (2012). Custo de produção e rentabilidade na cultura da pitaya sob o efeito de adubação orgânica. Científica, Jaboticabal, 40, 138-149. 


\section{Macrothink}

Journal of Agricultural Studies

ISSN 2166-0379

2020, Vol. 8, No. 2

Melquíades J. (2018). Pitaya: Beleza poderoza. Diário do Nordeste. [Online] Available: https://diariodonordeste.verdesmares.com.br/editorias/verso/pitayabeleza-poderosa-1.189829 6 (April 29, 2019)

Mizrahi, Y. (2014). Vine-cacti Pitayas: the new crops of the world. Revista Brasileira de Fruticultura, Jaboticabal, 36, 124-138. https://doi.org/10.1590/0100-2945-452/13

Oliveira, M. D. M. et al. (2010). Custo de produção da cultura do feijão na região sudoeste paulista. Análises e Indicadores do Agronegócio, São Paulo, 5, 1-5.

Perween, T., Mandal, K., \& Hasan, M. (2018). Dragon fruit: An exotic super future fruit of India. Journal of Pharmacognosy and Phytochemistry, 7, 1022-1026. E-ISSN: 2278-4136; P-ISSN: 2349-8234. [Online] Available: http://www.phytojournal.com/archives/2018/vol7issue2/PartO/7-1-435-453.pdf. (April 5, 2019)

Pitaya do Brasil. Sobre a Pitaya. [Online] Available: https://www.pitayadobrasil.com.br/sobre -a-piatya/ (March 19, 2018)

Pushpakumara, D. K. N., Gunasena, H. P. M., \& Singh, V. P. (Eds.) (2007). Underutilized fruit trees in Sri Lanka. World Agroforestry Centre, South Asia Office: India, p.110-142.

\section{Copyright Disclaimer}

Copyright for this article is retained by the author(s), with first publication rights granted to the journal.

This is an open-access article distributed under the terms and conditions of the Creative Commons Attribution license (http://creativecommons.org/licenses/by/4.0/). 